ARCHIVO ESPAÑOL DE ARTE, LXXXI, 323

JULIO-SEPTIEMBRE 2008, pp. 271-290

ISSN: 0004-0428

\title{
D. MELCHOR DE MOSCOSO Y SANDOVAL $(\dagger 1632)$ y BALTASAR DE ACEVEDO Y ZÚÑIGA († 1622), DOS PERSONAJES DE LA CORTE ENTERRADOS EN EL MONASTERIO DE EL PAULAR
}

\author{
POR

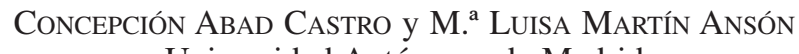 \\ Universidad Autónoma de Madrid
}

En el presente artículo analizamos, en base a documentación inédita, dos enterramientos del monasterio de El Paular. Uno pertenece a D. Melchor de Moscoso y Sandoval, obispo de Segovia, que consagró la iglesia en 1629. El otro es el de D. Baltasar de Acevedo y Zúñiga, primer ministro de Felipe IV, que eligió la Sala Capitular, como capilla funeraria para él y su familia. Estudiamos el proceso constructivo, así como la ornamentación de esta última, en el contexto de la fábrica del monasterio. Finalmente, damos a conocer las causas que motivaron el traslado de los restos de D. Baltasar al convento de las Agustinas de Salamanca.

Palabras claves: El Paular; Baltasar de Zúñiga; Melchor de Moscoso; Capilla funeraria; Sepulcro.

Using unpublished documentation, the authors examine two burials at the Monastery of El Paular. One of these pertained to D. Melchor de Moscoso y Sandoval, Bishop of Segovia, who consecrated the church in 1629. The other was commissioned by D. Baltasar de Acevedo y Zúñiga, Prime Minister to Felipe IV, who chose the chapter house as a funerary chapel for himself and his family. We study the construction process of these tombs and their ornamentation within the context of the monastic building. Finally, we explain why D. Baltasar's mortal remains were moved to the Augustine convent of Salamanca.

Key words: El Paular; Baltasar de Zúñiga; Melchor de Moscoso; Funerary chapel; Tomb.

Ya analizábamos en un trabajo anterior la vinculación de algunas familias de la nobleza castellana con el monasterio de El Paular, desde el mismo momento de su fundación ${ }^{1}$. Ahora nos vamos a centrar en dos personajes, descendientes de una de ellas, que eligieron la Cartuja como lugar de descanso eterno. Se trata de Melchor de Moscoso y Sandoval y D. Baltasar de Acevedo y Zúñiga, que se encuadran en dos ramas genealógicas, iniciadas en los hijos de Diego López de Zúñiga († 1479), I conde de Miranda (fig. 1).

${ }^{1}$ Concepción Abad Castro y M. a Luisa Martín Ansón, "Los Herrera y su Capilla funeraria de San Ildefonso en la Cartuja de El Paular”, Anuario del Departamento de Historia y Teoría del Arte, UAM, vol. XVIII, 2006, pp. 31-47. 


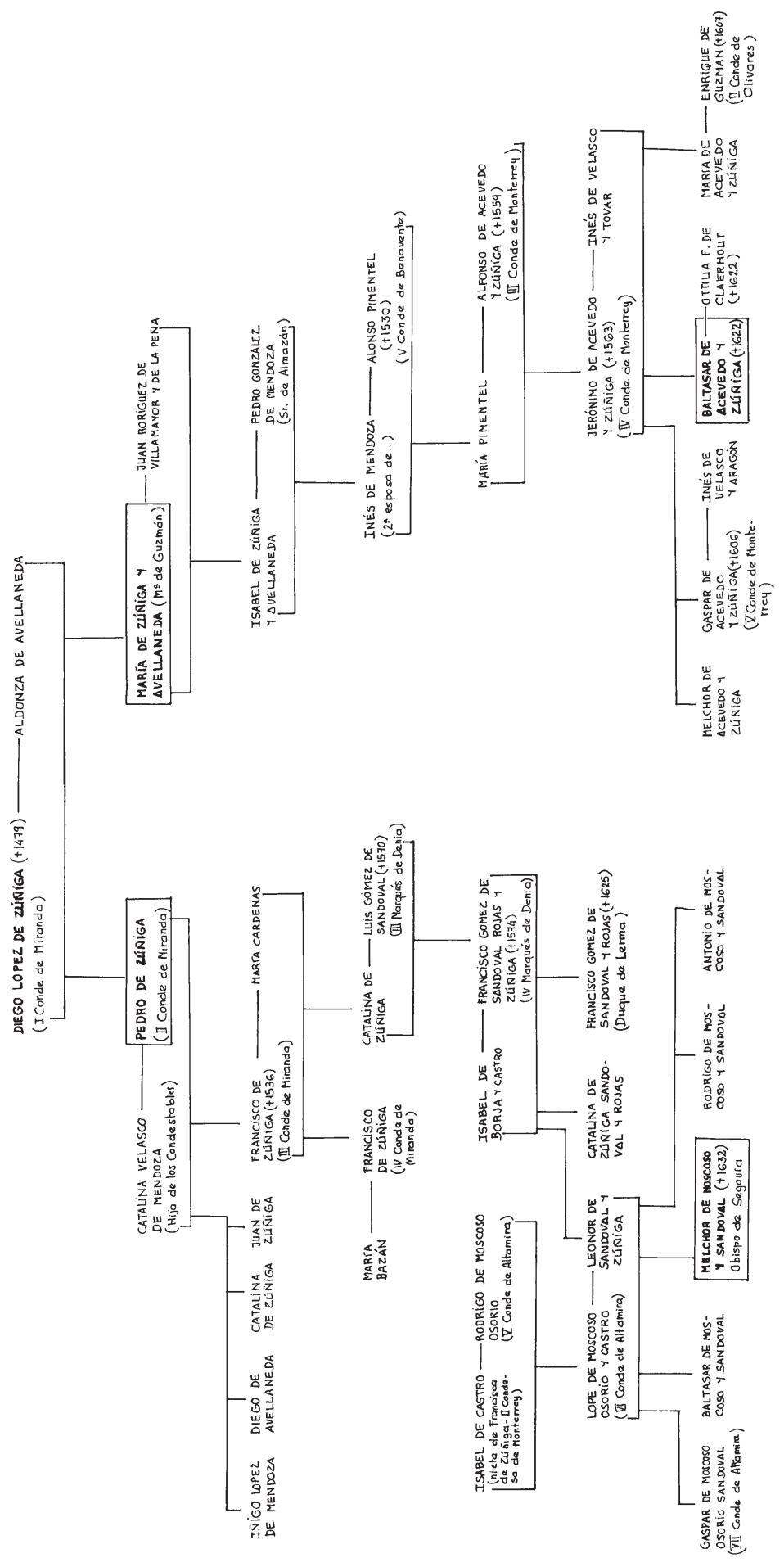

Fig. 1. Cuadro genealógico. 
Se trata de dos figuras prácticamente contemporáneas que viven de cerca los difíciles años del reinado de Felipe III (1598-1621) y las primeras décadas del de Felipe IV (1621-1665). Participan de la llamada "crisis del siglo XVII", marcada por una sucesión de problemas, tanto de índole exterior, como peninsular, ante los que el estado y las instituciones, sumergidas en una imbricada red de intereses, no parecen acertar con la solución. Protagonista de excepción en este tiempo fue Francisco Gómez de Sandoval, duque de Lerma desde 1599, valido del rey, que llevó a la Corte a varios familiares y personas de su linaje. Fue el caso de Juan de Zúñiga y Avellaneda, VI conde de Miranda, su consuegro, que entre otros cargos detentó el de Presidente del Consejo de Castilla; Pedro Fernández de Castro, VII conde de Lemos, sobrino y yerno del duque, que fue Presidente del Consejo de Indias, virrey de Nápoles y Presidente del Consejo de Italia; o Bernardo de Rojas y Sandoval, su tío, Arzobispo de Toledo, Consejero de Estado e Inquisidor General.

Igualmente, fue familiar suyo Melchor de Moscoso y Sandoval. Hijo de Lope de Moscoso Osorio y Castro, VI conde de Altamira, y de Leonor Sandoval y Zúñiga, hermana del duque, era, por tanto, su sobrino ${ }^{2}$. Fue rector de la Universidad de Salamanca, catedrático de teología, arcediano de Alarcón, canónigo de Cuenca y capellán de los Reyes en Toledo. Participó, junto a Lope de Vega, en el tribunal que juzgó el certamen poético, celebrado en Madrid, en octubre de 1614, con motivo de la beatificación de Santa Teresa, decretada por el Papa Pablo V, unos meses antes ${ }^{3}$. Igualmente compuso unos versos dedicados al sepulcro de San Ignacio de Loyola con motivo de la fiesta de su beatificación ${ }^{4}$. Estuvo también presente en la corte, como miembro del Consejo del Rey, hasta 1624, año en que fue apartado de ella por el otro gran protagonista de este tiempo, Gaspar Felipe de Guzmán y Pimentel, el conde-duque de Olivares (†1645). Era un momento en que Felipe IV atravesaba una grave enfermedad, que hacía temer por su vida y, en consecuencia, obligaba a pensar en su sucesión. El conde-duque, recelando de la proximidad que Moscoso mostraba hacia el Cardenal Infante D. Fernando, le hizo retirar de la corte, sustituyéndole precisamente por su hermano, Antonio de Moscoso, que él creía más cercano a sus pretensiones, aunque después no fue asi 5 .

La salida de la corte de Melchor de Moscoso fue emparejada con su nombramiento como obispo de Segovia, cargo en el que permaneció hasta $1632^{6}$. Precisamente, como tal consagró

\footnotetext{
${ }^{2}$ Fue descendiente en sexta generación de D. Diego López de Zúñiga $(† 1479)$ en la línea de su hijo Pedro de Zúñiga.

${ }^{3}$ Diego De SAn Joseph, Compendio de las solenes fiestas que en toda España se hicieron en la Beatificación de N.B.M. Teresa de Iesus fundadora de la Reformación de Descalzas y Descalzos de N.S. del Carmen en prosa y verso, impreso en Madrid, por la viuda de Alonso Martín, año 1615, fol. 175r.

${ }^{4}$ De Don Melchor de Moscoso, hijo de los Condes de Altamira. Ad Sepulchrum S. Ignatii de Loyola. Quis iacet hoc tumulo gelido sub marmore clausus?. / Signa Deum dicunt, sed breuis urna uirum. / Si uir, cur toties inscriptum nomen Iesu / marmor habet?. Quod ei Christus amicus erat. / Lugere ergo nefas, nam qui hoc gaudebat amico, / et fruitur felix posteritate sua, / non moritur, quamuis Latia tellure quiescat, sed uiuit qua uult uiuere parte magis.

Al sepulcro de San Ignacio de Loyola. ¿Quién, encerrado bajo el gélido mármol, yace en este túmulo? Las señales declaran a Dios pero la insignificante urna dice que es un hombre. Si hombre, ¿por qué el mármol tiene tantas veces escrito el nombre de Jesús? Porque Cristo era su amigo. Así pues, no es lícito lamentarse. Ya que, el que goza de este amigo y, feliz, disfruta de su posteridad, no muere aunque descanse en tierra Lacia; sino que vive en el lugar donde más desea vivir.

Alonso de SAlaZAr, Fiestas que hizo el insigne collegio de la Compañía de Iesvs de Salamanca, A la beatificación del gloriofo Patriarcha S. Ignacio de Loyola. Con los Sermones, y Poesias, que vuo en alabança del Santo. Dedicadas al Illuftrifsmo. y Rmo. Señor Maximiliano de Austria, Salamanca, Año de M.DC.X.

5 Veáse al respecto: M. K. Hoffman-Strow, "Carved of Rings and Painted in Pictures", en The Education and Formation of the Spanish Royal Family, 1601-1634, Yale University, 1966, p. 397. J. H. ElLIOT, The Count-Duke of Olivares. The Statesman in an Age of Decline, New Haven and London, 1986, pp. 185-186 y 308-310 (Edic. Castellana, Barcelona, 1990).

${ }^{6}$ En algunos textos se señala el año 1627 como fecha de su nombramiento como obispo. Sin embargo, tal como se constata en las propias Actas Capitulares de la catedral segoviana, la toma de posesión debió producirse en el mes de noviembre de 1624. El día 22 de este mes ya recibió como obispo la visita de su hermano, el marqués de Almazán, D. Gaspar de Moscoso y Sandoval. Libro de Acuerdos. Actas Capitulares del año 1624, 22 de noviembre, fol. 889v.
} 
la iglesia y los altares del monasterio de Santa María de El Paular, en 1629, según consta en la inscripción conservada a los pies de la iglesia, en el muro norte ${ }^{7}$ : A.D. D.O.M. AE.L. TEMPLVM HOC PRISCA INITIATIONE SACRVM. NOVA DIVINI VNGVENTI DELIBVTIONE, CVM TRIBVS EIVS ALTARIBVS SANCTIVS, ET AVGVSTIVS EFFECIT ILLUSTRISSIMVS ET REVERENDISSIMVS DOMINVS MELCHIOR DE MOSCOSO, EPISCOPVS SEGOVIENSIS, ANNVENTE HISPANIARVM PRIMATE. DIE XI. IVLIJ. ANN DOMINI MDCXXIX

A partir de algunas informaciones antiguas, se ha señalado de forma errónea que, tras esta visita a El Paular, Melchor de Moscoso renunció a la sede segoviana y se retiró al monasterio donde fue monje hasta su muerte en 1632. F. Villegas especifica que, a pesar de que ese era efectivamente el deseo del obispo, no se llegó a concretar, porque la bula papal que le dispensaba del cargo llegó después de su muerte ${ }^{8}$. De hecho, en 1631, según consta en las Actas Capitulares de la catedral, de 8 de marzo, D. Melchor de Moscoso, siendo obispo donó a la misma un Cristo yacente'. Lo cierto es que permaneció en el cargo hasta el mismo día de su muerte, que se produjo el 1 de septiembre del mencionado año de 1632 y después fue trasladado a El Paular donde, efectivamente, fue enterrado. Así se constata en las Actas capitulares de la catedral: "Cabildo en Segovia, miércoles por la tarde 1. ${ }^{\circ}$ de septiembre de 1632 años/ este día a las cinco de la tarde aviendose juntado el Cabildo Capitularmente/ Propuso el sr Dean como el sr. Obispo en su enfermedad estava tan al fin/ de la vida que los de su casa prevenian los lutos y funerales disponien/dolo para llevarle al Convento de la Cartuja del Paular donde/ se mandava enterrar y que parecia justo nombrase el Cabildo/ quatro Comisarios que acompañasen el cuerpo y fueron/ nombrados los señores Arcipreste y Prior y Doctor Francisco/ Triana y Licen(cia)do Pedro Tobalina". En el margen se especifica: "murio a las seis de la tarde"10.

Tal como vemos en este texto, el obispo había ordenado que se le enterrara en el monasterio de El Paular y lo lógico es que lo hiciera mediante su propio testamento, que nos consta fue leído de forma expresa en el capítulo celebrado el día 7 de septiembre, especificándose que nombraba al propio cabildo como testamentario ${ }^{11}$. Sin embargo, desgraciadamente, éste no se encuentra en el archivo catedralicio ${ }^{12}$.

${ }^{7}$ Los altares son los que acababan de colocarse por entonces en el coro, cuyo costo ascendió a 16.000 mrs., según consta en el Libro de Arcas desde el año de 1619 al de 1644. Gastos diversos. 28 de noviembre de 1628. "16.000 mrs. que pagamos al Padre procurador este dia en esta manera y son los dos retablos colaterales que costaron la dicha cantidad 8.000 mrs. de la arquitectura y 8.000 el dorar", AHN, Sección Clero, Sig. Libro 8090. Publicado por Mercedes Agulló Cobo, "El Arte del Paular en los documentos del Archivo Histórico Nacional", en Anales del Instituto de Estudios Madrileños, XIV, 1977, p. 84. También tenemos noticia documental de la propia piedra de consagración: "800 reales que costó la piedra de consagración que se puso en la iglesia, asentadas y esculpidas las letras como esta este dia", 15 de junio de 1630. Libro de Arcas..., publicado también por M. Agulló CoBo; Id., Anales del Instituto de Estudios Madrileños, XV, 1978, p. 118.

${ }^{8}$ Francisco DE VIllegas, La Cartuja de El Paular, Madrid-Buenos Aires, 1915, pp. 90-91.

${ }^{9}$ Se trata del Cristo de Gregorio Fernández, que hoy está en la capilla del mismo nombre (el Cristo yacente) en el lado meridional de la catedral. Veáse, por ej., J. Alonso Moreno, La Catedral de Segovia, 1987, p. 37.

10 ACS, Libro de Acuerdos. Actas Capitulares del año 1632, 1 de septiembre, fol. 32 r. Al día siguiente se hicieron los preparativos para el funeral del obispo: "Cabildo en Segovia juebes 2 de septiembre de 1632 años/ Este dia estando juntos Capitularmente los Señores/ Dean y Cabildo desta s(ant)a Iglesia considerando las obligaciones/ que ay al sr obispo nuestro Prelado se trata de hacerle un oficio fu/neral y propuniendo si iria el Cabildo a su casa a hacerle o/ se haria en esta Cathedral Acordo por Voto Secreto por mas/ conveniente y de mas autoridad se haga en esta Iglesia Previniendo/ sermón para el lunes y convidando a la ciudad y Caballeros" (fol. 32 v.).

11 "Cabildo en Segovia. Martes 7 de septiembre de 1632 años. Leyese el testamento del sr Obispo don Melchor de Moscoso que sea en gloria en el que nombra al cabildo por testamentario cuya testamentaria acepto y para acudir a lo que tocase y sea necesario en esta raçon nombro por sus coms ${ }^{\circ}$ s a los Sres Arcipte y Predro Tobalina can ${ }^{\circ}$ ". Id. fol. $33 \mathrm{r}$.

${ }_{12}$ Queremos agradecer el interés y la profesionalidad mostrada por el personal del Archivo de la catedral de Segovia, cuando les hemos consultado acerca de la documentación relacionada con el obispo. 
En efecto, D. Melchor de Moscoso fue enterrado en El Paular, en el ángulo noroeste del claustro, donde se conserva su sarcófago exento, cubierto con tapa tallada a doble vertiente, de una sola pieza, en la que figuraba una inscripción, hoy perdida casi en su totalidad (fig. 2). Ésta recorría la cubierta sur y partiendo de una cruz, al menos, ocupaba cuatro líneas, de las que sólo se adivinan algunas letras. En el lado occidental sí se conserva lo que sería el final de la inscripción, donde se hace referencia a la fecha de su muerte: OB. XXX.AVG. AN (NO) M.D.C. XXXII, que, como vemos, y a la vista de los datos expuestos más arriba, no coincide con el día del fallecimiento registrado en las Actas Capitulares, que es el 1 de septiembre. Quizá el hecho de que el sepulcro se realizara unos años más tarde justifique este error ${ }^{13}$.

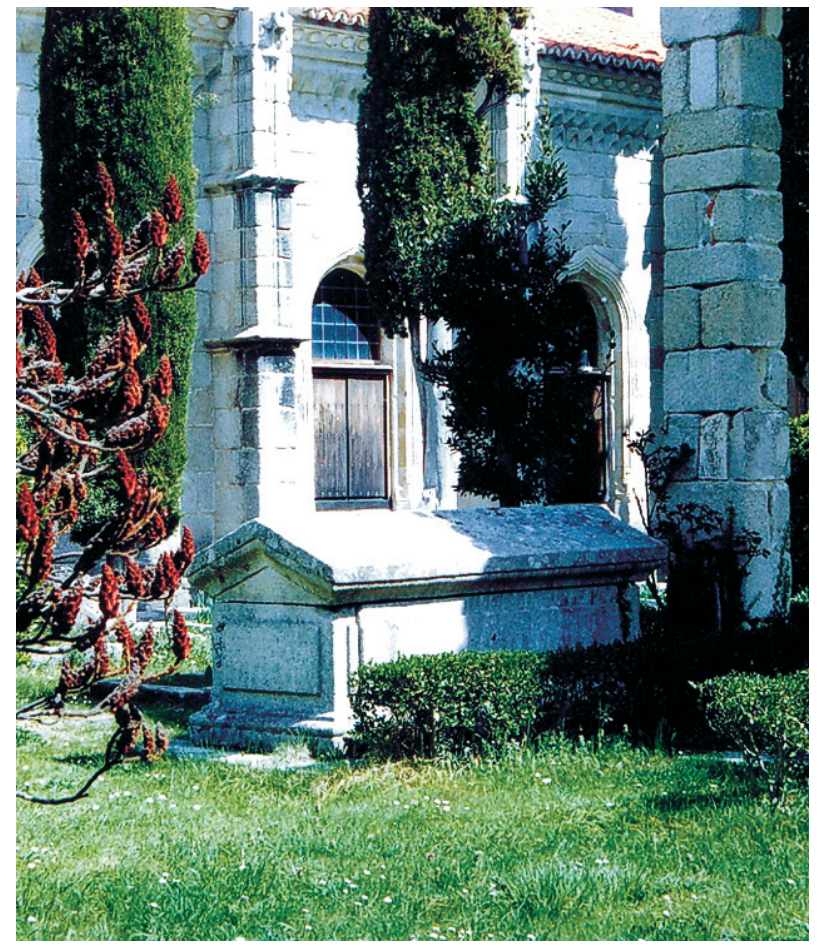

Fig. 2. Monasterio del Paular.

Sepulcro del Obispo Moscoso en el claustro.

Retomando el hilo conductor del marco histórico en que viven nuestros dos personajes, a partir de 1607 aproximadamente, el edificio que el duque de Lerma había creado en torno suyo, comenzaba a resquebrajarse, especialmente a causa de la política exterior. Y, en estas circunstancias, emergieron algunas figuras que apostaban por una actuación internacional radicalmente distinta a la impulsada por Lerma. Fue el caso del duque de Osuna, el marqués de Villafranca y, especialmente, de Baltasar de Zúñiga, nuestro segundo protagonista, acerca del cual disponemos de una información más extensa.

${ }^{13}$ La obra del sepulcro se registra en las cuentas de septiembre de 1641: "veinte mil reales que dio a un maestro de cantería que vino a concertar la obra del sepulcro del Señor Obispo", Libro de gasto Ordinario y Extraordinario desde el año de 1633 a el de 1653, AHN, Clero, publicado por Mercedes Agulló CoBo, op. cit., XV, 1978, p. 118. Podría pensarse que en principio fue enterrado de forma sencilla y años después, se realizó el sepulcro, colocándose encima de la tumba propiamente dicha. 
La obligada intervención del rey en materia de política exterior, quizá acelerada, entre otros acontecimientos, por la llamada "crisis de Bohemia", divergía en gran medida de los postulados del duque que, por entonces, se había quedado sin apoyos, al haber desaparecido de su entorno sus más leales colaboradores. Estas y otras circunstancias provocaron su expulsión de la corte en 1618, tras haber recibido el nombramiento de cardenal de San Sixto, siendo sustituido por su propio hijo, el duque de Uceda. Mientras tanto, Baltasar se perfilaba como un personaje clave en el Consejo de Estado.

La nueva política centralista iniciada por el monarca, como solución de choque a la difícil situación que se atravesaba, incluía, no obstante, la actividad sobresaliente de algunos personajes como el duque del Infantado, Filiberto de Saboya y el propio Baltasar de Zúñiga. Era una persona de amplia experiencia, sobre todo en cuestiones internacionales, tanto diplomáticas como militares. De igual modo, conocía muy bien la problemática interna de la política castellana de entonces y era considerado como persona de notable integridad y capacidad de trabajo.

Baltasar de Acevedo y Zúñiga (1561-1622) fue también descendiente en sexta generación de D. Diego López de Zúñiga, a partir de la línea de su hija María de Zúñiga y Avellaneda. Era hijo de los IV condes de Monterrey, D. Jerónimo de Acevedo y Zúñiga y de Doña Inés de Velasco y Tovar, hermana del Condestable don Íñigo Fernández de Velasco. Hermanos de D. Baltasar fueron Gaspar de Acevedo y Zúñiga, que ostentó el título de V conde de Monterrey, Melchor de Acevedo y Zúñiga y María de Acevedo, también llamada María Pimentel de Fonseca. Esta última contraería matrimonio con Enrique de Guzmán y serían los padres de Gaspar Felipe de Guzmán Pimentel y Acevedo, el conde-duque de Olivares, que se convertirá así en sobrino de Baltasar, afianzándose aún más el parentesco al casarse el conde-duque con Inés de Acevedo y Zúñiga, hija de Gaspar, su hermano (fig. 3).

D. Baltasar, tras estudiar en la Universidad de Salamanca, se hizo soldado y zarpó con la Armada Invencible rumbo a Inglaterra, en 1588. Durante un tiempo ejerció la diplomacia en Roma, junto a su cuñado Enrique de Guzmán, II conde de Olivares y, finalmente, pasaría a la Corte. Felipe III le nombró embajador de España en la corte de los Archiduques Alberto e Isabel en Bruselas, cargo en el que permaneció desde 1599 hasta 1603, y donde, posiblemente, conoció a la que sería su esposa Ottilie Françoise de Claerhout, hija del barón de Maldeghem, Jacques van Claerhout y de Doña Francisca de Ogniez. Fue también embajador en París, entre 1603 y 1606, y en la corte imperial de Praga, entre 1608 y 1617, año en que fue requerido a la Corte para ocupar por primera vez su plaza en el Consejo de Estado. En 1619 es consejero de Felipe III, quien le nombra comendador de la Orden de León y ayo del príncipe.

Precisamente a comienzos del reinado de este último, ya Felipe IV, en 1621, le fue encomendada la dirección de España como primer ministro. Baltasar tenía por entonces sesenta años y le restaban sólo 18 meses de vida, pues falleció en octubre de 1622. Poco después lo haría su esposa $^{14}$.

Junto al conde-duque de Olivares, su sobrino, llevaron a cabo una serie de reformas, en el marco del nuevo proyecto político que requería la situación y la presencia de un nuevo rey. Cabe pensar que en un primer momento, pese a la diferencia de edad y experiencia de ambos, existía entre ellos una comunión de ideas, pues los dos participaron de ese mismo proyecto político que pretendía volver al estado de la época de Felipe II. Sin embargo, muy pronto, el conde-duque,

\footnotetext{
${ }^{14}$ Respecto a los detalles biográficos y de la actividad política de Baltasar, veáse, entre otros: Carmen BoLAÑoS MeJías, "Baltasar de Zúñiga, un valido en la transición", en Los Validos, coord. José Antonio Escudero, Madrid, 2004, pp. 243-276; E. GONZÁLEZ LóPEZ, Los políticos gallegos en la Corte de España y la convivencia europea, Vigo, 1969, pp. 82-90; Virgilio MALveZZI, Historia de los primeros años del reinado de Felipe IV, Londres, 1968.
} 


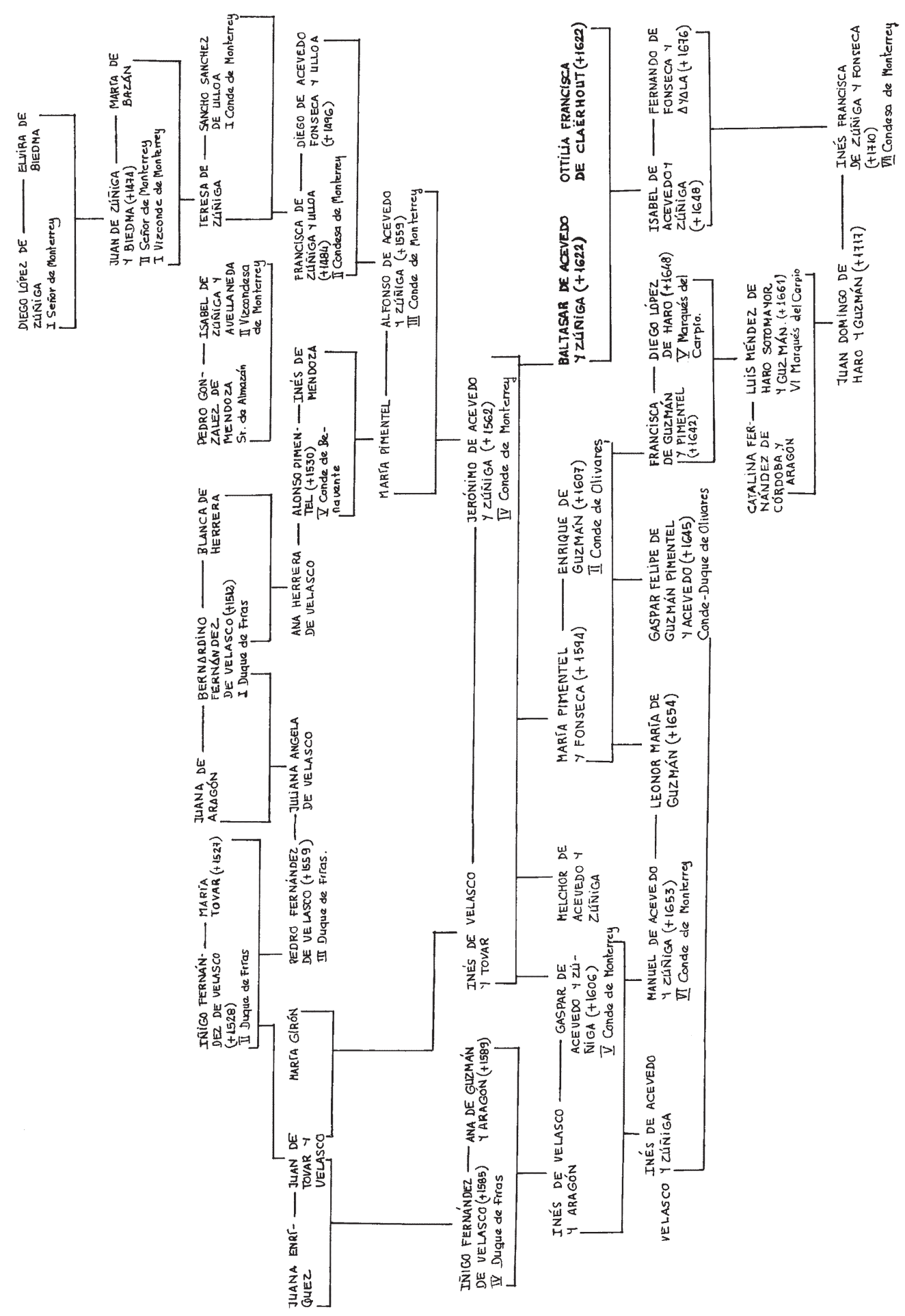

Fig. 3. Cuadro genealógico. 
poco dado a estar en la sombra, inició su carrera particular, surgiendo desavenencias entre ellos, que pervivieron, al parecer, hasta la muerte de Baltasar ${ }^{15}$.

Ocho meses antes de morir, Baltasar de Zúñiga, expresa al prior del monasterio de El Paular, que por entonces era D. Juan de Polanco, su deseo de recibir sepultura junto a su familia en la sala capitular de los monjes, que se convertiría así en su panteón. Este deseo, tras recibir el beneplácito del prior y monjes del convento, quedó plasmado en una escritura de concierto de 20 de marzo del mismo año, donde se estipulan las condiciones del enterramiento, así como la dotación por parte de D. Baltasar y las obligaciones del monasterio ${ }^{16}$

15 Gregorio Marañon, El Conde-Duque de Olivares. La pasión de mandar, Ed. Espasa, Madrid, 2006, pp. 80-81, señala que es muy improbable que fueran ciertas las murmuraciones, que ya empezaron entonces, sobre si D. Baltasar, celoso del predominio de su sobrino, tuvo desavenencias con él; incluso, cuando enfermó D. Baltasar, con rápida muerte a los siete días, se dijo que el Conde-Duque le había envenado. A pesar de su edad, en 1621 tuvo un hijo, al que el Rey hizo grandes mercedes, siendo fastuoso su bautizo en la Encarnación, con la Condesa de Olivares como madrina, y padrino el Monarca: le llevaba a la pila el Valido en una suntuosa bandeja. En octubre de 1622 murió D. Baltasar, en Palacio. El mes siguiente murió la viuda, D. Francisca Clarut, de tristeza. El hijo murió en 1625. J. H. ElLIOT, op. cit., p. 103, apunta que las relaciones entre tío y sobrino se deterioraron pocos meses antes de su muerte, debido en parte a un enfrentamiento entre sus respectivas esposas.

La actuación política del conde duque quedó expresada, como es sabido, en el "Gran Memorial" de 1624 y su actividad se prolongó hasta 1643, con gran oposición desde dentro de la corte. Basta señalar la figura de Manuel de Moura y Corte Real, II marqués de Castel Rodrigo, a quien nos referiremos después, que siempre se mostró contrario al rey y a Olivares, y partidario de los Infantes. Era señor de las Capitanías de Andrés y San Jorge, Comendador Mayor de Alcántara, embajador de Roma, gobernador de Flandes, Gentilhombre de Cámara de su Majestad y Mayordomo Mayor del rey Felipe IV.

El nacimiento del príncipe Baltasar Carlos en 1629 parecía despejar la sombra de la sucesión, pero los grandes problemas surgidos especialmente con Francia, Portugal y Cataluña debilitaron la privanza del conde-duque. Dos años antes de su muerte (1645), fue cesado de la corte y se retiró a su casa palacio de Loeches, siendo sustituido por su sobrino Luís de Haro. Precisamente, el hijo de este último, Juan Domingo de Haro y Guzmán, contraería matrimonio con la nieta de Baltasar, Inés Francisca de Zúñiga y Fonseca, y serán los VII condes de Monterrey. El título lo heredarían al morir sin descendencia Manuel de Acevedo y Zúñiga, sobrino de Baltasar, y Leonor de Guzmán, hermana del condeduque, VI condes, a quienes nos referiremos después.

${ }^{16}$ Escritura de Baltasar de Zúñiga, 20 de marzo de 1622, AHPM, Protocolo n. ${ }^{o}$ 2031, fols. 541-546. Transcribimos exclusivamente los párrafos referentes al Capítulo: “(...) Esta cierto el d(ic)ho poder y assi lo certifico yo el escrivano publico y lo/ accepto el dicho Padre Prior don Juan de Polanco y quiere usar del/ y haziendolo y mediante el dicho su officio de Prior por si y los/ Perlados y religiosos que adela(n)te fueren en dicho Monesterio por/ quien presta caucion para que cumpliera cada uno en su tiempo lo q(ue) //(fol. 541) contendra esta escritura para siempre jamas como el dicho poder/ lo dizen dixeron dicho Sr. Don Balthazar de Zúñiga y Padre Pri/ or don Juan de Polanco que esta tratado por parte de su Ex ${ }^{\mathrm{a}}$ con el/ dicho Padre Prior y demas religiosos del dicho Monesterio de tener en el/ para si y la dicha Señora su muger Señores sus hijos y decendientes/ y Señora su Suegra entierro a su disposición del Sr. don Balthazar/ y con sufragios perpetuos y fundallo y establecello en el d(ic)ho con/ vento para que tenga perpetuidad, como lo quiere hazer su Exa del d(ic)ho Sr. don Balthazar de Zuñiga por el amor y devocion que/ tiene a la d(ic)ha religión y dalle por ello lo equivalente en que el/ d(ic)ho $\mathrm{P}(\mathrm{adr}) \mathrm{e}$ Prior y el d(ic)ho Monesterio y dichos religiosos del vieren y/ lo quieren acceptar por tener en su Convento tal entierro y de/ tales señores y para su effetto y que cada parte tenga titulo se/ guro de lo que fundare y se obligare y señala es estable y/ cierto para siempre otorgan de un acuerdo poniendolo en execu/ cion y conciertan lo siguiente.

Que su Exa del dicho S(eñ)or Don Balthazar elige y señala y/ pide al dicho $\mathrm{P}($ adr)e Prior y religiosos del dicho Monesterio de la/ Cartuxa de N. Señora del Paular de la d(ic)ha Ciudad de Segovia/ le den la Capilla de San Bruno que llaman el Capitulo Mayor o de/ los Monges pieça en que hoy los religiosos del d(ic)ho Monesterio hazen/ Capitulo al presente y la en que se hiziese en todo tiempo en do/ quier que se mudasse, para que sea entierro de su Exa y de la dicha/ Señora su muger, señores hijos y decendientes y Señora su Suegra a/ disposición del Señor Don Balthazar, como dicho queda y en/ esta dicha Capilla del Capitulo que es al presente y fuere adela(n)/ te y para siempre que elige y señala para el dicho entierro, se/ pongan Sus Sepulturas y escudos de armas, letreros y demas cosas/ que convinieren, según el estilo y costumbre de personas de su calidad/ y el dicho P(adr)e Prior por si y por el d(ic)ho Convento Prelados y religiosos que/ del son y fueren da en propiedad propia perpetuamente al/ dicho Señor don Balthazar de Zúñiga la dicha Capilla del dicho $\mathrm{Ca}$ / pitulo del dicho Monesterio como esta de presente o como estuviere/ en cualquiera parte do se mude toda enteramente sin limitacion alguna para que sea tal entierro de su Exa y Señora su muger, Señores Sus Hijos// (fol. 541 
Tal como D. Baltasar expresa, uno de los motivos que le inducen a escoger la Cartuja como panteón, es la existencia en él de "antiguas memorias del linaje y apellido de Zúñiga"17, a la par

v.) hijos y decendientes y Señora Suegra como queda dicho para siempre/ en la qual apodera desde luego a su Exa y le entrega esta escrittura/ para titulo y de poder para tomar la possesion como quisiere y/ sea bisto apreden della realmente con el dicho entrego desta escritura y/ se constituye y a su Convento por su inquilino y se obliga y le obliga/ y a los Prelados y Religiosos que del fueren para siempre lo haran/ assi cierto y seguro a su Exa y Señora su muger, Señores sus hijos y de/ cendientes y Señora su Suegra para el dicho su entierro y celebraran/ los sufragios que fundaran por esta escritura. de tal manera que/ libremente y sin impedimento alguno los han de recibir a todos y sin/ que por ello paguen cosa alguna cada vez que se offrezca al entierro/ en la dicha Capilla del dicho Capítulo sin que el dicho Monesterio Prela/ dos y Religiosos del lo dexen de cumplir ni pongan estorbo ni impedimento alguno, que no lo han de poner ni pondrán y renuncia por si y/ por ellos qualquier causa mayor o menor que se pueda offrecer, que/ no es imaginable en tales religiosos antes muestra por si y por ellos parti/ cular agradecimiento de haver escogido su Monesterio para su entierro que/ su Exa accepta y estima y para su perpetuidad se ponen las condicio/ nes siguientes.

(en el margen del siguiente párrafo pone: El Monesterio haviendosse dado la sucesión del P. Prior el Convento es obligado a llevar y mudar sus huessos y de los suyos a donde se mudase para que assi perpetuamente gozen del Sagrado de su Capitulo de la sombra de $\tan (. .$.$) religión).$

Que si sucediese mudarse el Monesterio o el dicho Capitulo a diffe / rente parte del dicho Monesterio de donde hoy esta en el en qual/ quier parte donde se mudasse por algun acontecimiento, ha de ser y permanecer el dicho entierro y su Exa del Señor don Balthazar de Zuñiga o las/ dichas Señoras Su muger y su Suegra y los dichos señores sus hijos y decendientes/ cada uno en su tiempo han de hazer el gasto de la boveda o entierro en el/ tal nuevo Capitulo y la traslación de los cuerpos pero el ornato y asseo/ del tal nuevo Capitulo queda a su voluntad y sin otra obligación que la/ dicha y en ello han de venir los Prelados y religiosos que entonces fueren/ y lo concierta desde luego para entonces y para siempre con su Exa/ el dicho P(adr)e Prior por si y por su Monesterio Prelados y religiosos que/ del fueren. Pero se capitula y declara que en caso que sucediesse la tal muda(n)ça/ que en la d(ic)ha Capilla del d(ic)ho Capitulo su Exa del Sr. don Balthazar/ de Zuñiga ha de poner a su voluntad escudos de armas en piedra/ o en bronze y con los letreros y ornato que le pareciere y por ahora// (fol. 542) dize que estos escudos han de ser dos de las armas reales del Rey y/ Reyna nuestros Señores que hoy son y debaxo dellos otros escudos de/ armas del dicho Sr. don Balthazar de Zuñiga y Señora Doña Francisca/ de Clarut su muger y en el suelo del dicho Capitulo una lamina de bron/ ze o piedra que cubra y cierre la sepultura y en ella y en las/ mas partes que le pareciere de las paredes los epitafios que quisiere/ su Exa que han de servir para tres inscripciones del dicho Señor/ Don Balthazar y de las dichas Señoras su muger y su Suegra. Y si los hi/ jos y decendientes de los dichos señores quisieren poner otras podran / hazerlo y la dicha lamina o piedra que cierre la sepultura se ha/ de poner rasa que no levante cosa alguna holladera igual con/ el suelo de manera que no haga embaraço a los religiosos que con / curren al dicho Capitulo ni sin permission del P(adr)e Prior y dellos se ha/ de hazer novedad de labor ni traça rexas ventanas luzes/ ni otra cosa alguna que mude la forma que hoy tiene el Capitulo ni/ su Exa quiere se haga, salvo ponerse la sepultura y epitaphios como dicho/ queda arriba en lo qual el dicho P(adr)e Prior consiente por si y su Mo/ nesterio Prelados y religiosos que del fueren.

Que el dicho Convento en ninguna occasión ni tiempo ha de poder/ cubrir ni cubra la dicha lamina o piedra de la sepultura, ni parte/ della con estera ni otra cosa que impida estar manifiesta y vista, que/ lo ha de quedar en toda ocasión y acaecim(ient)o salvo si su Exa del d(icho)/ Sr. Don Balthazar de Zuñiga y señores sus hijos y decendientes quisieren poner encima algun paño rico que se de por su voluntad al Convento/ para este effetto pero no se obligan a ello.

Que en las ocasiones de entierros de los dichos señores el gasto/ de cera tocante a los tales entierros haya de ser y sea a costa de/ su Exa y de sus decendientes.

Que en la dicha capilla del dicho capitulo en que funda/ su Exa el dicho entierro en ningun tiempo se ha de enterrar ni en / tierre ni deposite por poco ni mucho tiempo en forma alguna cuer/ po de otra persona que las de los dichos señores don Balhtazar de Zuñiga y Señoras su muger y Suegra y Señores sus hijos y decendientes a di/ sposicion del Señor don Balthazar el qual desde luego los prohibe// (fol. 542 v.) la enajenación de este entierro y quiere q(ue) en ningu(n) caso se exceda ni contra/ venga en lo dicho ni lo consientan los prelados y religiosos que por tiempo fue/ ren en el d(ich)o Monesterio y a ello se obligan y los obliga para siempre y/ para su observancia lo previene y pone en conciencia a cada prelado lo ha/ ga cumplir assi cada uno en su tiempo...”.

17 No olvidemos que los Zúñiga estuvieron presentes en el acto de fundación de la Cartuja y contribuyeron a la formación de su patrimonio inicial. Quizás esas antiguas memorias de su linaje y apellido que cita D. Baltasar, hagan referencia a estos hechos, pues, que conozcamos, no existe en El Paular ninguna memoria funeraria de esta familia, antes que la suya. 
de la especial devoción que él siente por la Virgen y por la Orden Cartuja "de quien ha recibido mucho favor y caridad".

Concretamente Baltasar pide al prior y convento que "le den la Capilla de San Bruno que llaman el Capítulo Mayor o de los Monges pieça en que hoy los religiosos del dcho Monesterio hazen capítulo al presente y la en que se hiziese en todo tiempo e doquier que se mudase", es decir que su deseo es ser enterrado con su familia en la Sala Capitular, que en este momento tiene el monasterio y, si se cambiase, al lugar donde aquélla fuera instalada, porque, como expresa más abajo, pretende gozar de las oraciones de los monjes de forma continuada. Y prosigue: "en esta dicha capilla del Capítulo que es al presente y fuera adelante y para siempre que elige y señala para el dicho entierro se pongan sus sepulturas y escudos de armas, letreros y demás cosas que convinieren, según el estilo y costumbre de personas de su calidad". El prior accede a esta petición y entrega la capilla con carácter de perpetuidad: "y el dicho padre Prior por si y por el dicho Convento Prelados y religiosos que del son y fueren da en propiedad propia perpetuamente al dicho Señor don Balthazar de Zuñiga la dicha Capilla del dicho Capitulo del dicho Monesterio como esta de presente o como estuviere en cualquier parte do se mude toda enteramente sin limitacion alguna para que sea tal entierro de su $\mathrm{Ex}^{\mathrm{a}}$ y Señora su muger, señores sus hijos y decendientes y Señora suegra".

Se estipula también, de común acuerdo, que, si por alguna circunstancia el capítulo se cambiara de sitio o el propio monasterio se trasladara, quede a voluntad de D. Baltasar colocar emblemas y realizar los ornatos pertinentes. Concretamente en el momento de redactar la escritura, se concierta que deben colocarse los escudos de "las armas reales del Rey y Reyna nuestros señores que hoy son y debaxo dellas otros escudos de armas del dicho Sr. Don Balthazar de Zúñiga y Señora Doña Francisca Clarut su muger y en el suelo del dicho Capitulo una lámina de bronze o piedra que cubra y cierre la sepultura y en ella y en las mas partes que les pareciere de las paredes los epitafios que quisiere su $\mathrm{Ex}^{\mathrm{a}}$ que han de servir para tres inscripciones del dicho Señor / Don Balthazar y de las dichas señoras su muger y su suegra y si los hijos y descendientes de los dichos señores quisieren poner otras podran hazerlo y la dicha lamina o piedra que cierre la sepultura se ha de poner rasa que no levante cosa alguna holladera igual con el suelo de manera que no haga embaraço a los religiosos que concurren al dicho Capitulo ni sin permission del Padre Prior y dellos se ha de hazer novedad de labor ni traça rexas ventanas luzes ni otra cosa alguna que mude la forma que hoy tiene el Capitulo...".

Respecto a los sufragios por las almas de D. Baltasar y su familia se establece una misa rezada diariamente en el mismo capítulo, un trecenario que debe comenzar la víspera de la festividad de San Matías, el 23 de febrero, y tres misas cantadas y responsos en los aniversarios de los fallecimientos, más otras tres de igual solemnidad, una en la fiesta de los Reyes y dos en la de San Francisco.

Como dotación de la capilla, sufragios, etc., entrega al monasterio la renta y pensión de los frutos del Arcedianato de Écija en Sevilla que le fueron concedidos por el Papa. Asimismo, se compromete a entregar al Monasterio buena parte de las reliquias que tienen en su oratorio, cuando fallezcan, y señala que, después, se puede llevar a la capilla el cuerpo de su hijo D. Jerónimo de Zúñiga, ya fallecido, y que, por entonces, estaba depositado en la iglesia de Santa María de Atocha.

Y llegados a este punto, es obligado referirnos a la propia Sala Capitular o Capilla de San Bruno, que ha de convertirse en panteón de los Zúñiga y el devenir posterior de los acontecimientos relacionados con el enterramiento de D. Baltasar. 


\section{La Sala Capitular del Monasterio}

Se sitúa en el lado meridional de la iglesia (fig. 4). Fue construida en el último tercio del siglo XVI, sustituyendo al antiguo capítulo de los monjes que, quizá para entonces, se había quedado pequeño ${ }^{18}$. Ocupó el lugar donde previamente se levantaba el Claustro de la Recordación $y$, de hecho, la puerta que hoy da acceso a la sala desde el templo, pudo ser en origen la entrada a este claustro, ya que presenta un derrame hacia el interior del capítulo, circunstancia cuando menos extraña. Dibuja un arco apuntado, decorado con cuadrifolios, motivo, que se repite en algún otro vano del monasterio, dentro de las construcciones del siglo XV.

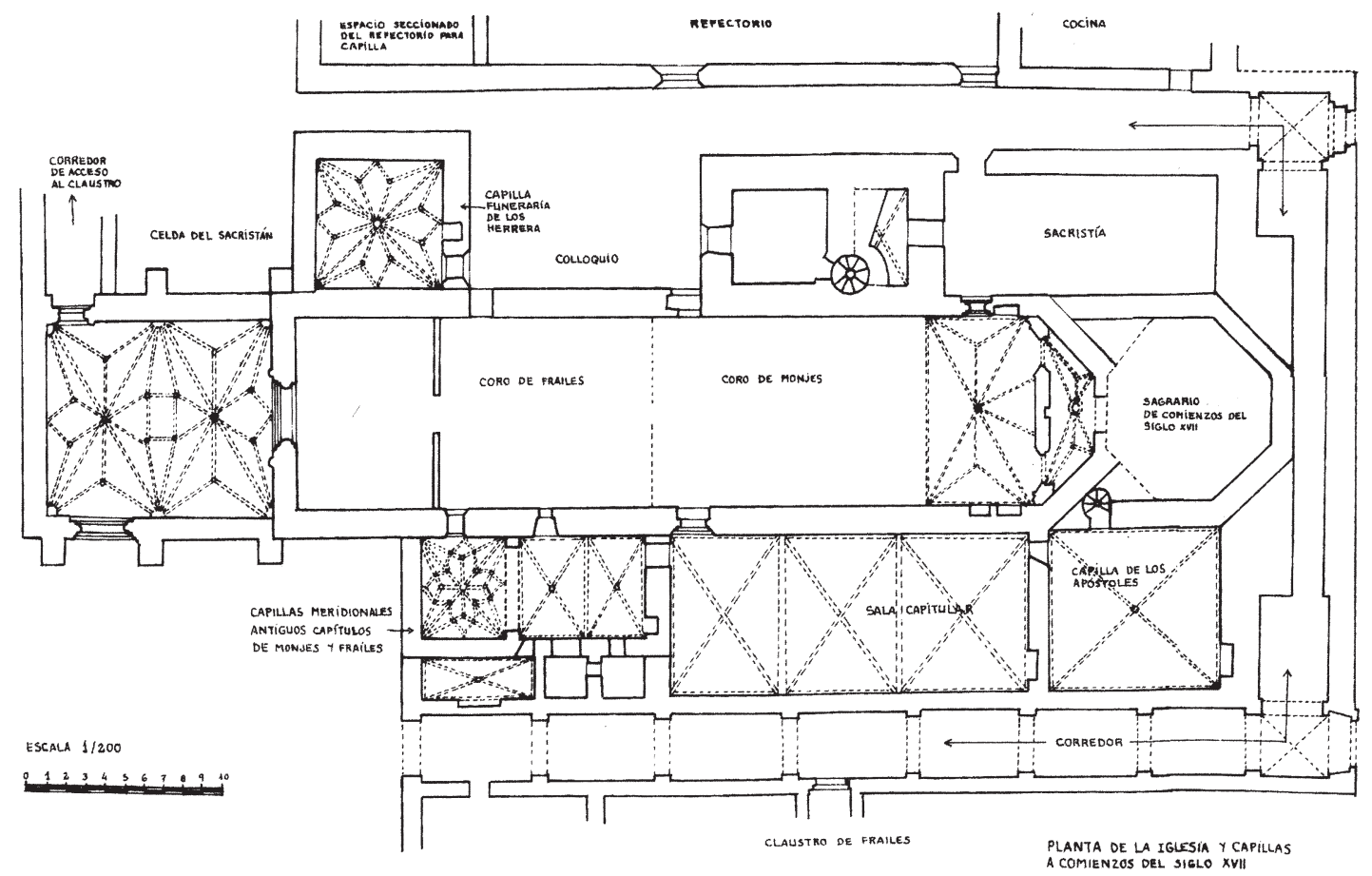

Fig. 4. Planta de la iglesia y capillas a comienzos del s. XVII.

Su edificación se inserta en un momento en que se procede a dotar a la cartuja de un sistema de ambulación que permitiera a los frailes moverse hacia las estancias que debían ser atendidas por ellos, sin necesidad de pasar por el templo. Se ideó para ello el corredor que discurre de forma paralela a éste, abrazando todas las capillas del lado meridional y discurriendo de forma

18 Es una estancia de reducidas dimensiones, ubicada a occidente de la nueva sala capitular, cubierta con bóveda de crucería y junto a ella, se sitúa el capítulo de los frailes, ambas construidas a mediados del siglo XV, de acuerdo a las proporciones que por entonces presentaba el templo. Pueden identificarse con las capillas que en el siglo XVIII se denominan como "la Antigua" y la de "San José". En palabras de Antonio Palomino, El Museo pictórico. Madrid, 1715-1724, pp. 652 y 878, la capilla de la Antigua "es la primera como se entra a la Sala del Capítulo", y la de San José "que es la segunda como se va al Capítulo". 
subterránea por debajo del sagrario, para desembocar, tanto al norte donde se situaba la cocina y el refectorio, como al este, alcanzando así la zona de la bodega, el noviciado y la huerta del monasterio. Este corredor constituye hoy la entrada al mismo.

La obra corrió a cargo de Nicolás y Juan de Ribero, como consta por los pagos efectuados en los años ochenta de las obras realizadas: "Yten se redescargan /.../ dos quentos y seiscientos y diez y ocho mil mrs. que dio gastados en las obras de cantería extraordinarias desta Casa que son las capillas y callejón y demás obras... Los quales dichos mrs. dio pagados a Nicolás y Juan de Ribero su sobrino, maestros de cantería"19. Nicolás y Juan de Ribero seguramente llegaron a El Paular de la mano de Rodrigo Gil de Hontañón, artista que trabaja en el monasterio en los años sesenta y a quien se atribuye, entre otras obras, la puerta de acceso al mismo (hoy entrada al hostal $)^{20}$.

Actualmente la Sala Capitular es un espacio cubierto por bóveda de cañón con lunetos, dividida en tres tramos, que arrancan de una amplia imposta decorada con angelotes y frutos policromados, todo ello realizado en yeso. En el testero occidental se conserva un escudo de Castilla, sostenido también por parejas de ángeles, mientras el oriental está presidido por el retablo (figs. 5 y 6). Estructurado este último en tres calles, mediante columnas salomónicas por las que trepan angelotes agarrándose a una trama de pámpanos y vides. Hoy presenta, en la hornacina central una Inmaculada, imagen procedente de uno de los altares de separación de los coros de monjes y frailes en la iglesia. Fue colocada en el retablo sustituyendo una talla de San Bruno, a quien estuvo siempre dedicado el capítulo, que era, al parecer, obra de Pedro Alonso de los Ríos ${ }^{21}$. En los laterales vemos dos santos cartujos, quizá San Hugo y San Antelmo, y en el cuerpo superior, figura un Calvario, a cuyos pies se dibuja un escudo de la Cartuja, con las siete estrellas de ocho puntas, sostenido por ángeles. En la parte inferior se abren dos pequeñas puertas que conducen a la capilla más oriental, dedicada a los Santos Apóstoles, desde la que se accede al transparente ${ }^{22}$.

A pesar de esta apariencia y desnudez actuales, la Sala Capitular debió ser uno de los ámbitos más monumentales del monasterio, como se deduce de diversos datos documentales y descripciones antiguas, que nos permiten reconstruir de forma aproximada su fisonomía a partir de mediados del siglo XVII. Así, nos consta que a partir de los años cuarenta de esta centuria, se interviene en el capítulo, en aspectos relacionados especialmente con su ornato. En 1644 están trabajando en él Mateo y Eugenio Orozco, a quienes se les paga "quinientos cuarenta reales de diez apóstoles a cuarenta y quatro reales y el tablero de Nuestro Padre San Bruno... más de treinta y ocho días que trabaxan a jornal en el capitulo y reçibimiento... Se concertó con Eugenio y Mateo Orozco el hacer los doce cuadros de El Credo que están puestos en nuestro capítulo, se concertó el dorar los marcos de dichos cuadros a catorce reales cada uno..."23.

19 Libro de Gasto Ordinario y Extraordinario del año de 1582 hasta el de 1587, AHN, Clero, Sig. 8457.

${ }^{20}$ Tío y sobrino estuvieron ligados al maestro, heredando alguna de sus obras como la iglesia de Valdefinjas, la de Miraflores de la Sierra o la capilla de los Bonales del Convento de San Esteban de Salamanca, por citar algunos ejemplos.

21 Veáse Cayetano Enríquez de Salamanca, Santa María de El Paular, Madrid, 1974, p. 98, según señala, esta figura de San Bruno fue trasladada a la iglesia parroquial de Rascafría. Antonio Ponz no duda en calificar la escultura como "obra muy apreciable", Viaje de España, t. X, vol. III, ed. Madrid, 1988, p. 260.

${ }^{22}$ Esta capilla debió ser construida de forma paralela a la Sala Capitular y el corredor mencionado. Conserva aún la bóveda de crucería original y muestra un zócalo revestido de azulejos talaveranos del siglo XVIII, en los que se incluyen diversos escudos con emblemas de La Pasión, las estrellas de la Cartuja y uno, situado en el lado meridional, con las armas de Felipe V. Igualmente son visibles aún diversas pinturas atribuidas a Eugenio Orozco, en los tímpanos de los cuatro muros, donde se perfila una completa iconografía en relación con los santos titulares.

${ }^{23}$ Libro de pagos por diversos conceptos 1640-1653, cuentas de 6 de octubre de 1644, AHN, Clero, sig. Libro 19.821 . 


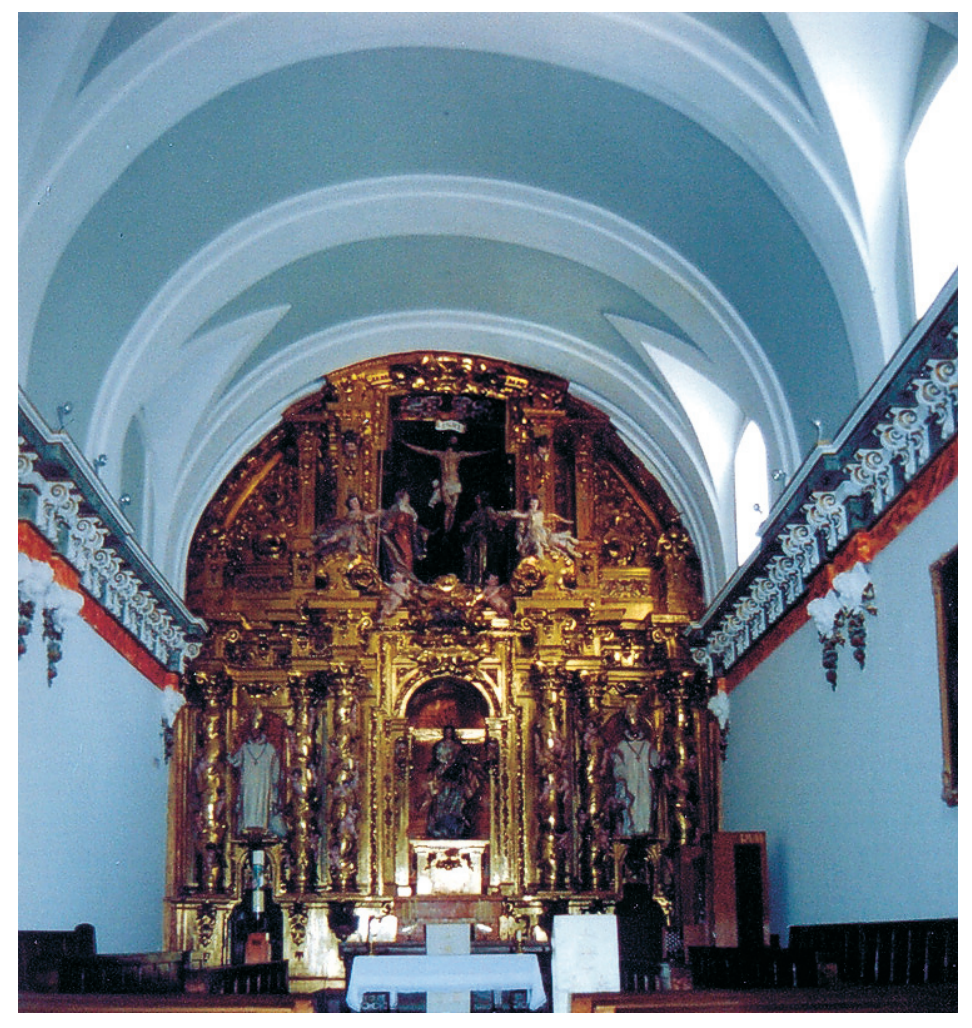

Fig. 5. Sala Capitular hacia el altar.

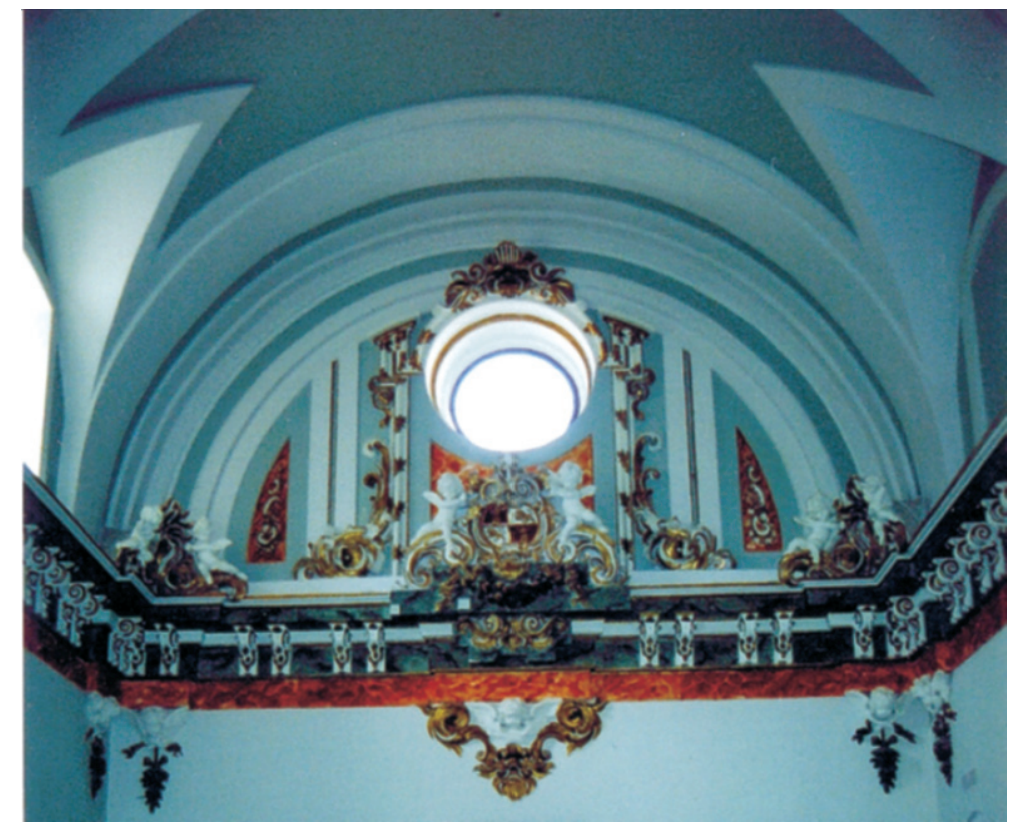

Fig. 6. Sala Capitular hacia los pies. 
En los años cincuenta debió procederse a una remodelación, como parece deducirse de algunas noticias, por otro lado algo imprecisas. En 1651 se "adereza" el capítulo y se menciona a Juan Carrillo y Cuesta, quien recibe cien reales por su intervención en él y en la hospedería ${ }^{24}$. En 1667 se pagan a Luperçio Falces cinco mil quinientos reales que se le debían por la "obra que hiço en el capitulo", expresión que indica la anterioridad de la misma ${ }^{25}$. Entre 1668 y 1672 se procede a decorar el techo de la Sala Capitular con frescos que reproducen tres episodios alusivos a la vida de San Bruno, obra atribuida a Claudio Coello y José Donoso ${ }^{26}$.

Por último, antes de efectuarse la transformación de la cubierta, que ocultaría los frescos mencionados, se realizó el retablo que hoy vemos, en sustitución de otro anterior -no documentado-, tal como se especifica en el contrato que en 1701 firma el procurador de El Paular con el arquitecto y ensamblador madrileño José de la Torre ${ }^{27}$. A la par del retablo, el mismo artista realizó la nueva sillería que también vino a ocupar el lugar de otra anterior y que sería trasladada tiempo después, como la de la iglesia, a San Francisco el Grande de Madrid ${ }^{28}$.

En la época en que A. Ponz visita el monasterio, en la Sala capitular, según sus palabras, había "catorce cuadros alrededor, seis de fray Juan Sánchez Cotán, seis de Wanders.Hamen y dos de Lanchares que exceden a los otros en el gusto de color y están firmados: "Antonius Lanchares Hispanus in Cartusia Paularis fecit anno 1620"29.

Como vemos, las obras pictóricas documentadas para la Sala Capitular en 1644, y que mencionábamos más arriba, fueron sustituidas por otras en algún momento, pero el hecho es que un siglo después ya no estaban, tal como acabamos de constatar a través de la descripción de Ponz. Posiblemente los cuadros de los apóstoles realizados por Eugenio Orozco fueron colocados posteriormente en la Capilla contigua dedicada a San Pedro y San Pablo y las doce pinturas del Credo, obra de Mateo Orozco, que a mediados del siglo XVII estaban en el Capítulo, una centuria después tampoco figuraban en él.

Pero, ¿cómo era la Sala Capitular en el año 1622, fecha en que Don Baltasar escoge precisamente este ámbito para su enterramiento familiar? Se cubría con una bóveda gótica, similar a las de los espacios colindantes, que debemos también relacionar con Nicolás y Juan de Ribero. Estaba estructurada en tres tramos de crucería y, presumiblemente, con un perfil de nervios idéntico a los que aún se conservan en las capillas contiguas (fig. 7). Por otro lado, ya contaba entonces con una sillería, sobre la cual nada podemos aventurar, en lo que se refiere a su forma y ornato, que fue realizada también por Juan de Ribero, como se constata en una partida de gastos registrada entre 1581 y 1583: "Gastos de carpintería. Seiscientos cincuenta y seis mil maravedis que dio gastados en la obra de carpintería pertenecientes a las capillas y callejón y los asientos del capitulo, los quales maravedis dio pagados a Juan de Ribero carpintero desde el veintiocho de Agosto de mil quinientos ochenta y uno hasta oy diez y siete de diciembre de mil quinientos y ochenta y tres"30. Finalmente el Capítulo estaría presidido por un retablo o quizá un lienzo, dedicado a San Bruno, advocación que tuvo desde su origen y como se le designa en la propia escritura de Baltasar de Zúñiga.

${ }^{24}$ Id., cuentas de 1651 y 1652.

25 AHN, Clero, Leg. 4316, documento publicado por Mercedes Agulló, op. cit., p. 96.

${ }^{26}$ Véase Antonio PonZ, op. cit., p. 260 y Cayetano EnRíqueZ de Salamanca, op. cit., p. 96.

27 Véase Virginia Tovar Martín, "José de la Torre en la Real Cartuja de Santa María del Paular", en Anales del Instituto de Estudios Madrileños, vol. XIV, 1977, pp. 53-67. La autora señala la posibilidad de que el retablo anterior fuera obra de José Ratés, que trabajó en la cartuja cincuenta años antes y que se reaprovecharían en el nuevo algunas piezas del precedente.

${ }^{28}$ Cayetano EnRíQueZ DE SALAMANCA dice que constaba de 40 sitiales, construidos con respaldos y simples bancos, sin brazales de separación y agrupados de tres en tres. En la crestería que remataba cada grupo, siguiendo sus palabras, figuraba en el centro el escudo de la Cartuja entre dos ángeles y, a los lados, el de Castilla entre parejas de águilas, op. cit., p. 98.

${ }^{29}$ Antonio PonZ, ob. cit., p. 260.

${ }^{30}$ Libro del Gasto Ordinario y Extraordinario del año 1582 hasta el de 1587, op. cit. 


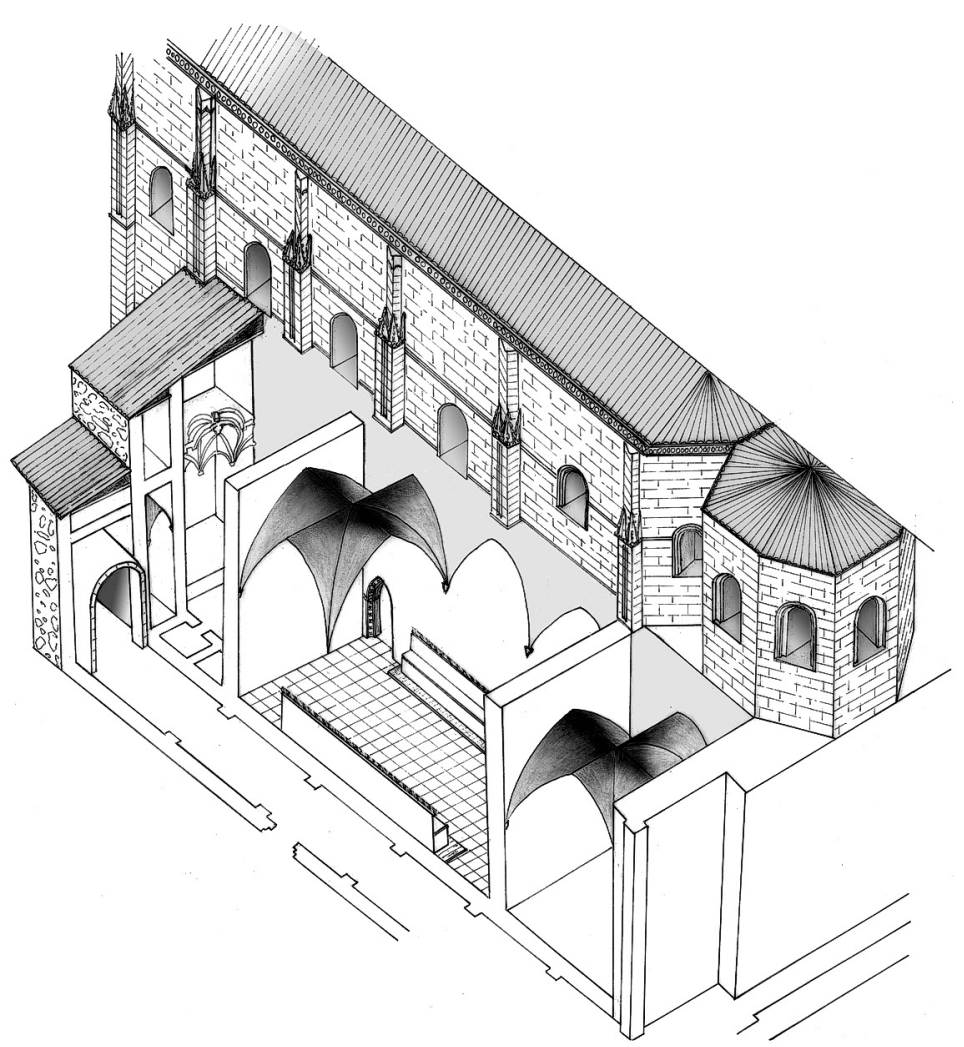

Fig. 7. Alzado hipotético de la Sala Capitular, capillas e iglesia a comienzos del s. XVII.

Se trataba, pues, de un ámbito relativamente austero en aquel tiempo, en cuyo suelo expresa su deseo de ser enterrado D. Baltasar, con una lámina de bronce o piedra que cubra y cierre la sepultura que debe quedar a ras del pavimento para que los monjes no encuentren obstáculo en sus movimientos en el interior de la sala. Llega a prohibir a los monjes incluso que se coloque sobre ellas ninguna estera o similar que impida que la lápida quede vista. Sólo si sus descendientes quisieran cubrirla con paños ricos podían hacerlo a su voluntad, que no es, como vemos, la del propio Baltasar.

En la misma escritura insiste en que no debe añadirse ni colocarse ninguna labor de ornato, ni siquiera rejas en las ventanas o hacer cambio alguno que afecte a la forma que por entonces presentaba el Capítulo. Debemos imaginar pues que únicamente las lápidas de Baltasar, su esposa, su suegra y su hijo Jerónimo, ya fallecido en aquellas fechas, con sus armas y epitafios colocados en las propias lápidas o en algún otro lugar, hablarían de la doble función que desde entonces habría de cumplir la Sala Capitular.

Sin embargo, resulta extraño que en ninguna de las noticias documentales, que hemos relacionado más arriba, se haga mención alguna a la existencia de los enterramientos en la Sala Capitular, ni de los posibles epitafios con las armas de los Zúñiga, que habrían de colocarse tras su muerte, hecho que se produjo sólo unos meses después de la escritura. Tampoco se ha podido documentar vestigio material alguno de las inevitables fosas que habrían de practicarse en el suelo para recibir los cuerpos ${ }^{31}$. Ante

31 Hemos consultado a D. Eduardo Barceló, arquitecto que ha llevado a cabo la última intervención restauradora en el monasterio, acerca de este particular y nos ha confirmado que en el subsuelo de la Sala no apareció testimonio alguno de la existencia de enterramientos. Aprovechamos estas páginas para agradecerle su amabilidad. 
esta circunstancia, realmente llegamos a plantearnos si en efecto los restos de D. Baltasar y su familia fueron inhumados, como era su deseo, en la Sala Capitular, ámbito que, por otra parte, y contraviniendo lo expresado en la escritura, sí recibió diversos ornatos y transformaciones con posterioridad a 1622.

Que estuvieron enterrados, al menos los esposos, en El Paular, es un hecho, como veremos después, pero ¿dónde? Podría pensarse, en el campo de la hipótesis, que no reposaron en la Sala Capitular, sino quizá en algún lugar de las capillas contiguas, las más occidentales, donde existen determinados espacios y arcos en los muros que quizá constituyeran un marco adecuado (fig. 8).

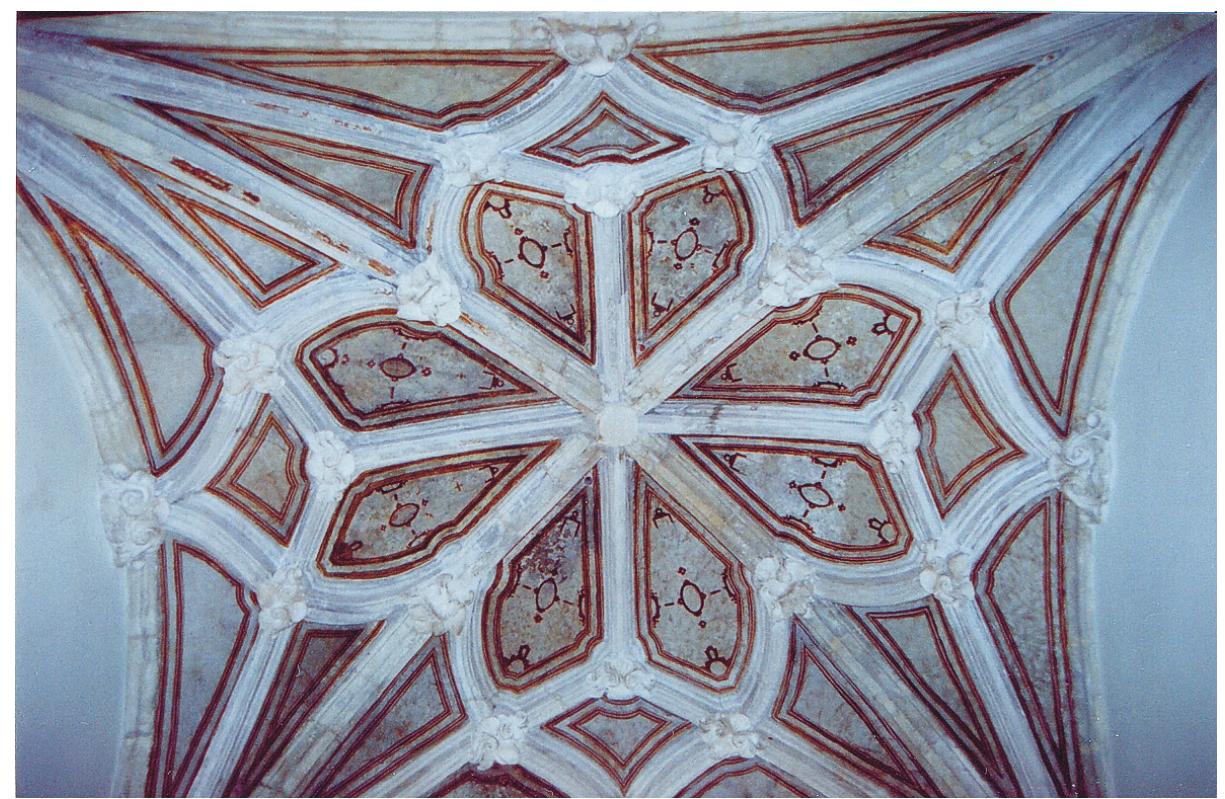

Fig. 8. Bóveda de una de las capillas contiguas (antiguo capítulo).

Sabemos que en 1657, los restos mortales de D. Baltasar y su esposa fueron trasladados desde El Paular -dato que confirma que efectivamente estuvieron allí, sin que conste el lugar exacto- hasta el convento de las agustinas de Salamanca. Esta interesante noticia la conocemos a través de un documento conservado en el archivo del convento salmantino ${ }^{32}$, donde se establece que las Agustinas cobrarán, por este traslado, una renta de 103.499 reales al año, producto de los beneficios eclesiásticos de Écija, que el Papa Gregorio XV había otorgado a D. Baltasar, para que lo aplicase al monasterio donde fuese enterrado. Con ello, como es obvio, la Cartuja de El Paular, dejaría de percibir esta cantidad que el propio Baltasar le otorgó en la mencionada escritura de 1622. Este traslado se justifica porque, al parecer, el Prior y los monjes de El Paular no habían dado a D. Baltasar el trato acorde a su condición y, acaso, no habían cumplido los acuerdos pactados en aquélla, entre los que se encontraba el más importante, descansar en la Sala Capitular.

Y ¿por qué las Agustinas de Salamanca? D. Baltasar era tío de D. Manuel de Zúñiga (15821653), a quien había acogido como un hijo, junto a su hermana Doña Inés, al quedar éstos

32 AAR cajón VII, Leg. I, referenciado por Ángela MAdruga ReAL, Arquitectura barroca salmantina. Las Agustinas de Monterrey, Salamanca, 1983, p. 63. 
huérfanos de madre, siendo muy jóvenes y estando su padre D. Gaspar de Acevedo y Zúñiga, V conde de Monterrey, en América. Este afecto de D. Baltasar hacia el futuro conde de Monterrey, será recompensado, posteriormente, por Manuel de Zúñiga y su esposa, Leonor de Guzmán -su prima y hermana del conde-duque de Olivares- como quedará patente en varias acciones llevadas a cabo por ellos. La más notable, y que afecta al interés de nuestro trabajo, fue el deseo expreso de D. Manuel de que los restos de su tío reposaran junto a los suyos propios.

Hacia los años treinta, D. Manuel estaba proyectando construir un panteón familiar que acogería también a sus tíos. En principio, el lugar elegido fue la iglesia de las Úrsulas, fundada por D. Alonso de Fonseca, arzobispo de Santiago, cuyo espléndido sepulcro, obra de Gil de Siloé, preside aún, en el centro, la capilla mayor, y que constituyó también el panteón de los condes de Monterrey. En efecto, allí recibieron sepultura hasta el 5. ${ }^{\circ}$ titular, don Gaspar, padre de D. Manuel, que murió y fue enterrado de limosna en Lima, a pesar de su expresada voluntad de reposar junto a su esposa Inés de Velasco y Guzmán, igualmente en las Úrsulas ${ }^{33}$.

D. Manuel, probablemente queriendo descansar, junto a sus antecesores, entre los que no estaba su padre pero sí su madre, poco después de su llegada a Nápoles, en 1631, de donde fue virrey, ideó llevar a cabo una remodelación de las Úrsulas. En 1633 suscribe un contrato con Cosimo Fanzago para ejecutar un altar columnado, cuatro nichos sepulcrales y otras obras menores, en mármoles embutidos, de acuerdo con los diseños firmados por Bartolomé Picchiatti y el propio Fanzago ${ }^{34}$. Estos cuatro nichos sepulcrales, según se ha interpretado, irían destinados a los propios condes y a D. Baltasar y su esposa, aunque no se especifica de forma concreta en la escritura de concierto: "El cavallero Cosme Fanzago escultor se obligo por servicio de su alteza el señor Conde de Mont Rey Virrey deste Reyno de Nápoles de hacer un ornamento de mármol para el Altar Mayor de la Capilla que su Alteza hace en la ciudad de Salamanca en el Convento de Monjas de Santa Úrsula con sus columnas çon las cinco figuras ansi mismo de Manuel que son un crucifisso con Nuestra Señora y Santo Juan Evangelista Santiago el Mayor y la Madalena y dichas figuras van al remate del ornamento del Retablo y más el ornamento de mármol de cuatro depósitos dos Apoyadores para las rejas y una losa para poner en tierra..."35.

Con esta intención, el conde, acaso quisiera que D. Baltasar que, a pesar de los muchos títulos que recibió, no ostentó el de Monterrey, descansara, no obstante, en el panteón familiar, ya que en su infancia había sido un padre para él.

Por distintas razones, entre las que quizá destaca la dificultad de acoplar en la Capilla Mayor de las Úrsulas el proyecto pensado, D. Manuel de Zúñiga y Fonseca se planteó llevar a cabo una nueva fundación que se situaría muy próxima a aquella. Será el Convento de las Agustinas Descalzas. Así se lo comunica el Conde al II Marqués de Castel Rodrigo, a quien nos hemos referido anteriormente, en una carta de 26 de febrero de 1636, en la que asimismo le expresa su voluntad de trasladar los restos de su tío desde El Paular hasta el nuevo convento salmantino para el que, según se señala, ha encargado ya un retablo y entierros para su sepultura ${ }^{36}$ : "en medio de los mayores cuidados no se puede dejar tal vez de aplicar el ánimo a las cosas propias, cuando no sea más que por diversión, y así yo siguiendo este dictamen estoy fundando en Salamanca una iglesia

\footnotetext{
33 Veáse: A. Casaseca Casaseca, "La huella de los Fonseca en la ciudad de Salamanca", en Erasmo en España. La recepción del humanismo en el primer Renacimiento español, Madrid, Seacex, 2002, p. 175.

${ }_{34}$ Veáse Fernando MARías, "Bartolomé y Francesco Antonio Picchiatti, dos arquitectos al servicio de los virreyes de Nápoles: las Agustinas de Salamanca y la escalera del palacio real”, Anuario del Departamento de Historia y Teoría del Arte, vols. IX-X (1997-1998), pp. 177-195.

35 Texto recogido por Damián Dombrowski, "Nápoles en España. Cosimo Fanzago, Giuliano Finelli, las esculturas del Altar Mayor en las Agustinas Descalzas de Salamanca y un monumento funerario desaparecido", Anuario del Departamento de Historia y Teoría del Arte, vols. VII-VIII (1995-1996), pp. 87-93.

${ }^{36}$ AHN Est., lib. 85, sin foliar, en Jonathan Brown y John H. Elliot, Un Palacio para el Rey. El Buen Retiro y la Corte de Felipe IV, Madrid, ed. 2003, cap. V, nota 44, p. 277.
} 
y convento de monjas agustinas descalzas, con intento de hacer allí un entierro para pasar a él los huesos del Sr. D. Baltasar (de Zúñiga) mi tío... que están en el convento del Paular de Segovia, por no haber querido aquellos frailes cumplir las memorias que les dejó con las disposiciones que ordenó se observasen en ellas, y también para enterrarme yo, que se vive de manera que certifico a V. E. que es alivio la memoria de morir. Para estos entierros he hecho hacer aquí algunos bultos y otras cosas de mármol, y también un retablo grande de diferentes piedras de estimación para el altar mayor de la iglesia; y habiendo procurado saber en la forma que el Duque de Alba, estando en el gobierno deste reino, envió las fuentes que hizo aquí para la Abadía, me han informado que fueron derechas a Lisboa desde aquí y que desde allí en barcas grandes las subieron por el Tajo arriba hasta Brantes porque era en verano, que en invierno o la primavera suelen subir hasta el puente de Alcantara, desde donde es camino de 35 leguas que lo andan carros de bueyes, aunque hay algunos pedazos de mal camino; y deseando que hagan el mismo viaje mis mármoles antes de tomar resolución en enviarlos, he querido comunicar a V. E. este pensamiento..."

Monterrey quería averiguar además si Castel Rodrigo poseía en Lisboa algún agente de confianza a cuyo cuidado pudiera confiarse el envío, y también si él mismo, como nativo de Portugal, podía hacer algo para evitarle las tasas de aduana.

La primera piedra del nuevo convento fue colocada el 17 de marzo de 1636 y a partir de esa fecha comenzaron las obras. La construcción de la iglesia discurre lentamente ${ }^{37}$. Pero, en este nuevo proyecto, al menos a la vista de lo edificado, ya son sólo dos los nichos que irán colocados en el altar mayor, donde habrán de recibir sepultura él mismo y la condesa. Sin embargo, de este hecho, no debe concluirse que la idea inicial de enterrar a su tío junto a él, había quedado en el olvido. La voluntad persiste pero, quizá de otra manera. Posiblemente D. Manuel tenía previsto construir una cripta funeraria en el centro de la iglesia, donde presumiblemente pensaba depositar los cuerpos de sus tíos.

El afecto del conde hacia su tío queda patente también en el hecho de que, no teniendo descendencia propia, en su testamento de $1647^{38}$ nombre a Isabel de Zúñiga, hija de D. Baltasar, no sólo como testamentaria, junto a Luis Méndez de Haro, su sobrino y conde-duque de Olivares y al Condestable de Castilla, su primo, que entonces era D. Bernardino Fernández de Velasco (1609-1652), sino que la designe heredera universal de todos sus bienes, la casa y estados de Monterrey, si a su muerte hubiera fallecido también su esposa D. ${ }^{a}$ Leonor. Esta circunstancia no se cumplió porque Isabel murió antes que Leonor. Pero la relación prosiguió, pues la Condesa en el suyo de $1654^{39}$, hace lo mismo pero en la persona de la hija de Isabel, Inés de Zúñiga, que habrá de contraer matrimonio con Juan Domingo de Haro y Guzmán, hijo de Luis su sobrino, para que pudiera efectivamente heredar la casa y Estados de Monterrey, como así ocurrió dos años después de morir D. ${ }^{a}$ Leonor de Guzmán. De tal manera, los nuevos condes de Monterrey serán Juan Domingo de Haro y Guzmán e Inés de Zúñiga, nieta de Baltasar (fig. 3).

Y desde nuestro punto de vista, quizá porque antes no había sido posible, van a ser ellos quienes lleven a efecto el traslado de los cuerpos de sus abuelos desde El Paular hasta el convento de las Agustinas de Salamanca, cumpliendo así la voluntad de D. Manuel. Esto ocurrió en 1657, el mismo año en que se había derrumbado la cúpula de la iglesia, y ellos mismos se hacen cargo de la reconstrucción y finalización de las obras. Todavía en estos años los cuerpos de los Condes, D. Manuel y D. ${ }^{a}$ Leonor, descansaban en la Sala Capitular del monasterio, donde permanecerían

\footnotetext{
37 Véase al respecto: Ángela MAdruga, op. cit. y Fernando Marías, op. cit. quienes no coinciden a la hora de establecer el proceso cronoconstructivo de la misma. A la muerte de los condes, en 1653 y 1654, los sepulcros no están concluidos.

38 Ángela MAdruga, op. cit., p. 42.

39 Id., p. 45.
} 
siempre, pues nunca fueron trasladados a sus nichos en el altar mayor, a pesar de que sus efigies sí estaban ya allít ${ }^{40}$.

Juan Domingo $(\dagger 1716)$ e Inés $(\dagger 1710)$ también expresaron su voluntad de ser enterrados en las Agustinas, pues no en vano se había concebido como panteón condal, y ellos mismos se habían hecho cargo de las obras desde 1657 hasta 1685, en que se dan por concluidas. En la cláusula del testamento de Juan Domingo se refleja claramente esta voluntad y se aportan datos curiosos: "Ytem es mi voluntad entregar luego al dcho Convento de Agnas. Recoletas de Salamanca la pintura de Santa Inés que tengo con su marco dorado que es de mano del pintor Jordan y está en la misma alcoba que Nuestra Señora de la Soledad; y assi mismo mando al dcho Conbento para después de mis dias la Cruz de Evano en que esta pintado un Santo Cristo y en los remates de la Cruz casquillos de oro, por ser el que ablo a D. Baltasar de Zúñiga a la hora de su muerte y haber espirado con el mi muger como yo lo hare si me permite Dios volver a Madrid. la dcha Cruz esta al presente en el dozel de la cama donde duermo de ordinario y con la dcha Cruz se dara tambien al Conbento el retrato que tengo de la hija que me nacio en Flandes donde murio, para que se coloque en el donde esta su cuerpo.

Y ruego y encargo a las dchas Religiosas encomienden a Dios a mi muger y a mi pues nuestros huesos han de ser trasladados al dcho conbento como patronos que hemos sido de el" 41 .

La cripta sería el lugar idóneo para recibir los cuerpos de D. Baltasar y sus descendientes, pero ésta nunca se llegó a utilizar a causa de las humedades y la inseguridad que siempre presentó en cuanto a su estabilidad.

Todo parece indicar que reposarían también en la Sala Capitular del monasterio de donde nunca salieron los Condes y donde aún permanecen tras una pared. Es curioso ver cómo al final D. Baltasar descansaría eternamente junto a su esposa en la Sala Capitular, pero no del monasterio de El Paular, como fue su deseo, sino en la del convento de las Agustinas de Salamanca. Y si él no quiso ningún ornato especial en el lugar de enterramiento, por circunstancias diversas, así fue finalmente. D. Baltasar, miembro de la familia de los Condes de Monterrey, pues lo fue su padre, D. Jerónimo; su hermano, D. Gaspar; su sobrino, D. Manuel y, por las circunstancias analizadas lo iba a ser su hija y finalmente lo fue su nieta, sin embargo, él no ostentó nunca el título de tal, como en algún lugar erróneamente se señala. Acaso por ello optó por ser enterrado en un lugar ajeno a los panteones familiares, pero la voluntad inicial de su sobrino y la decisión última de su nieta le llevó a hacerlo definitivamente junto a los suyos.

Fecha de recepción: 21-V-2007

Fecha de aceptación: 14-XII-2007

\footnotetext{
40 Sobre este particular, resulta extraña la desproporción de las esculturas respecto a los nichos, considerablemente grandes. Acaso la idea era colocar los enterramientos y sobre ellos los bultos. De esta forma, los huecos se habrían cubierto de manera más coherente.

41 Ángela Madruga, op. cit. Apéndice documental, doc. XLV, p. 235.
} 